\title{
Hubungan kebiasaan mandi di sungai dengan kejadian leukosituria pada anak di Kelurahan Karame
}

\author{
${ }^{1}$ Reifanli M. Pai \\ ${ }^{2}$ Adrian Umboh \\ ${ }^{2}$ Rocky Wilar
}

\author{
${ }^{1}$ Kandidat skripsi Fakultas Kedokteran Universitas Sam Ratulangi Manado \\ ${ }^{2}$ Bagian Ilmu Kesehatan Anak Fakultas Kedokteran Universitas Sam Ratulangi Manado \\ Email: reifanli@yahoo.com
}

\begin{abstract}
Leukocyturia is the precense of leukocytes in urine. If the presence of leukocytes is in large quantities in the urine then it is called pyuria. Leukocyturia is one of the symptoms of Urinary Tract Infection (UTI) which is one of the most frequent health problems in children. Leukocyturia is caused by an inflammatory process in the urinary tract, and is an indicator of suspected UTI. Gram-negative bacteria, particularly Escherichia coli, is the leading cause of UTI (85-90\%). The initial survey conducted at Karame village Singkil Manado assumed that the watershed in the area was contaminated by E. coli. This study aimed to determine the relationhip between bathing in the river with the incidence of leukocyturia in children. This was an observational analytical study with a cross sectional approach. Samples were obtained by using consecutive sampling method. The study was conducted at Karame village during November and December 2015. The results showed that there were 60 children aged 5-12 years as samples divided equally into groups of children with and without bathing habit in the river and had undergone urinalysis examination. There were 50 boys and 10 girls. Positive leukocyturia were found in 2 children (6.7\%) bathed in the river and 2 children (6.7\%) who did not bathe in the river. The Fisher exact test showed a $\mathrm{P}$ value $=0.694(>0.05)$. Conclusion: There was no relationship between bathing in the river with the incidence of leukocyturia in children
\end{abstract}

Keywords: bathing in the river, leukocyturia, urinalysis

\begin{abstract}
Abstrak: Leukosituria adalah terdapatnya leukosit di dalam urin. Bila terdapatnya leukosit dalam jumlah banyak dalam urin disebut pyuria. Leukosituria merupakan salah satu gejala Infeksi Saluran Kemih (ISK) yang merupakan salah satu masalah kesehatan yang paling sering terjadi pada anak. Leukosituria terjadi karena proses inflamasi di saluran kemih dan merupakan indikator kecurigaan infeksi saluran kemih (ISK). Bakteri gram negatif, khususnya Eschericia Coli, merupakan penyebab utama ISK (85-90\%). Survei awal yang dilakukan di Kelurahan Karame Kecamatan Singkil Kota Manado menduga bahwa daerah aliran sungai di daerah tersebut tercemar E. coli. Penelitian ini bertujuan untuk mengetahui hubungan antara kebiasaan mandi di sungai dengan kejadian leukosituria pada anak. Jenis penelitian ini analitik observasional dengan desain potong lintang. Sampel diperoleh dnegan metode consecutive sampling. Penelitian ini dilakukan di Kelurahan Karame selama bulan November Desember 2015. Hasil penelitian memperlihatkan sampel 60 anak yang berusia 5-12 tahun terbagi sama banyak atas yang memiliki kebiasaan mandi di sungai dan yang tidak, dan dilakukan pemeriksaan urinalisis. Sampel terdiri dari 50 anak laki - laki dan 10 anak perempuan. Hasil pemeriksaan positif leukosituria ditemukan pada 2 anak (6,7\%) yang mandi di sungai dan 2 anak (6,7\%) yang tidak mandi di sungai. Hasil uji Fisher exact menunjukkan nilai $P=0,694(>0,05)$. Simpulan: Tidak terdapat hubungan antara mandi di sungai dengan kejadian leukosituria pada anak.
\end{abstract}

Kata kunci: kebiasaan mandi di sungai, leukosituria, urinalisis 
Pai, Umboh, Wilar: Hubungan kebiasaan mandi...

Leukosituria merupakan salah satu gejala pada Infeksi Saluran Kemih (ISK). Leukosituria terjadi karena proses inflamasi di saluran kemih,dan merupakan indikator kecurigaan ISK. $^{1}$ Sekitar $8 \%$ anak perempuan dan $2 \%$ anak laki-laki pernah menderita ISK ketika berusia 11 tahun. Insiden ISK sepanjang usia anak, pada perempuan berkisar 30\% dibandingkan dengan laki-laki yang hanya 1\%. Sekitar $75 \%$ bayi berumur kurang dari 3 bulan yang mengalami bakteriuria ialah laki-laki sedangkan pada kelompok umur 3-8 bulan hanya $10 \%$. Setelah usia lebih dari 12 bulan ISK pada anak yang secara umum sehat kebanyakan ditemukan pada anak perempuan. $^{2,3}$

Bakteri Gram negatif, khususnya Eschericia coli merupakan penyebab utama ISK (85-90\%). Walaupun merupakan flora normal dalam tubuh (khususnya usus besar), E. coli sering juga ditemukan di alam bebas (air atau tanah yang tercemar kotoran manusia). ${ }^{4-7}$

Bakteria menyebabkan respon inflamasi saluran kemih namun gambaran klinisnya bervariasi. Pada penderita dengan pielonefritis akut terjadi inflamasi di ginjal dengan respon inflamasi secara umum misalnya demam, peningkatan C-reaktif protein, leukosituria. ${ }^{8}$

Sungai Tondano, sebagai salah satu sungai yang ada di kota Manado merupakan sungai yang paling tercemar dibandingkan sungai lainnya. Pencemaran sungai Tondano berkaitan dengan terdapatnya kandungan E. coli akibat kegiatan domestik maupun kegiatan masyarakat seperti mandi, mencuci, buang air dan lainlain di sepanjang sungai maupun daerah perkotaan yang membuang limbahnya ke sungai. Dari beberapa penelitian, diperoleh hasil bahwa sungai Tondano positif tercemar E. coli. ${ }^{9-11}$

Hasil survei yang dilakukan di Kelurahan Karame, Kecamatan Singkil, Kota Manado mengasumsikan bahwa sungai Tondano di daerah tersebut tercemar E.Coli. Penulis juga melihat bahwa anakanak di daerah tersebut masih memanfaatkan air sungai untuk mandi atau bermain-main. Jika demikian sangat mungkin anak-anak tersebut ada yang mengalami leukosituria. Untuk membuktikannya, perlu dilakukan urinalisis pada anak-anak yang memiliki kebiasaan mandi di sungai. ${ }^{4,5}$

Penelitian ini bertujuan untuk mengetahui hubungan antara kebiasaan mandi di sungai dengan kejadian leukosituria pada anak di Kelurahan Karame.

\section{METODE PENELITIAN}

Jenis penelitian ini analitik observasional dengan desain potong lintang. Penelitian ini dilakukan di Kelurahan Karame, Kecamatan Singkil, Kota Manado selama bulan November sampai Desember 2015. Populasi penelitian ialah semua anak yang tinggal di kelurahan Karame. Sampel penelitian ialah anak-anak berusia 5-12 tahun yang memiliki kebiasaan mandi di sungai dan yang tidak. Sampel diambil dengan cara consecutive sampling berjumlah 60 anak.

Variabel bebas penelitian ini yaitu kebiasaan mandi di sungai, dan variabel tergantung yaitu leukosituria. Pengumpulan data menggunakan kuesioner dan sampel diperiksa di laboratorium untuk dilakukan urinalisis. Data dianalisis dengan menggunakan uji Fisher exact.

\section{HASIL PENELITIAN}

Berdasarkan kuesioner, diperoleh jumlah anak yang berjenis kelamin laki-laki sebanyak 50 anak dan perempuan sebanyak 10 anak dengan jumlah total 60 anak. Dari jumlah tersebut ditemukan 1 anak leukosituria positif pada laki-laki (2\%) dan 3 anak leukosituria positif pada perempuan (30\%) (Tabel 1).

Berdasarkan kuesioner, diperoleh usia dengan angka kejadian leukosituria. Untuk anak berumur 5 tahun sebanyak 10 anak. Dari jumlah tersebut terdapat 1 anak leukosituria positif (10\%). Jumlah anak berumur 6 tahun sebanyak 3 anak. Dari jumlah tersebut tidak terdapat anak dengan leukosituria positif. Jumlah anak berumur 7 tahun sebanyak 8 anak. Dari jumlah 
tersebut terdapat 1 anak leukosituria positif (12,5\%). Jumlah anak berumur 8 tahun sebanyak 5 anak. Dari jumlah tersebut tidak terdapat anak dengan leukosituria positif. Jumlah anak berumur 9 tahun sebanyak 8 anak. Dari jumlah tersebut tidak terdapat anak dengan leukosituria positif. Jumlah anak berumur 10 Tahun sebanyak 8 anak. Dari jumlah tersebut terdapat 1 anak leukosituria positif (12,5\%). Jumlah anak berumur 11 tahun sebanyak 7 anak. Dari jumlah tersebut terdapat 1 anak leukosituria positif (14,3\%). Jumlah anak berumur 12 tahun sebanyak 11 anak. Dari jumlah tersebut tidak terdapat anak dengan leukosituria positif. (Tabel 2).

Berdasarkan kuesioner diperoleh jumlah anak yang memiliki kebiasaan mandi di sungai 30 anak dan yang tidak 30 anak. Dari jumlah tersebut yang memiliki kebiasaan mandi di sungai terdapat 2 anak leukosituria positif $(6,7 \%)$ sedangkan yang tidak memiliki kebiasaan mandi di sungai ditemukan juga 2 anak leukosituria positif (6,7\%) (Tabel 3).

Berdasarkan kuesioner, diperoleh durasi (dalam jam) mandi dengan angka kejadian leukosituria. Durasi mandi kurang dari 1 jam sebanyak 3 anak. Dari jumlah tersebut tidak terdapat anak dengan leukosituria positif. Durasi mandi lebih dari 1 jam sebanyak 27 anak. Dari jumlah tersebut terdapat 2 anak leukosituria positif (7,4\%). Sedangkan yang tidak meiliki durasi mandi sebanyak 30 anak. Dari jumlah tersebut terdapat 2 anak leukosituria positif (6,7\%) (Tabel 4).

Tabel 1. Distribusi kejadian leukosituria berdasarkan jenis kelamin

\begin{tabular}{ccccccc}
\hline Jenis & \multicolumn{2}{c}{ Leukosituria negatif } & \multicolumn{2}{c}{ Leukosituria positif } & \multicolumn{2}{c}{ Total } \\
Kelamin & $\mathrm{n}$ & $\%$ & $\mathrm{n}$ & $\%$ & $\mathrm{n}$ & $\%$ \\
\hline Laki-laki & 49 & 98 & 1 & 2 & 50 & 100 \\
Perempuan & 7 & 70 & 3 & 30 & 10 & 100 \\
Total & 56 & 93,3 & 4 & 6,7 & 60 & 100 \\
\hline
\end{tabular}

Tabel 2. Distribusi kejadian leukosituria berdasarkan usia

\begin{tabular}{ccccccc}
\hline $\begin{array}{c}\text { Usia } \\
\text { (tahun) }\end{array}$ & $\begin{array}{c}\text { Leukosituria Negatif } \\
\mathrm{n}\end{array}$ & \multicolumn{2}{c}{ Leukosituria Positif } & \multicolumn{2}{c}{ Total } \\
\hline 5 & 9 & 90 & $\mathrm{n}$ & $\%$ & $\mathrm{n}$ & $\%$ \\
6 & 3 & 100 & 0 & 10 & 10 & 100 \\
7 & 7 & 87,7 & 1 & 12,5 & 8 & 100 \\
8 & 5 & 100 & 0 & 0 & 5 & 100 \\
9 & 8 & 100 & 0 & 0 & 8 & 100 \\
10 & 7 & 87,5 & 1 & 12,5 & 8 & 100 \\
11 & 6 & 85,7 & 1 & 14,3 & 7 & 100 \\
12 & 11 & 100 & 0 & 0 & 11 & 100 \\
Total & 56 & 93,3 & 4 & 6,7 & 60 & 100 \\
\hline
\end{tabular}

Tabel 3. Distribusi kejadian leukosituria berdasarkan kebiasaan mandi di sungai

\begin{tabular}{|c|c|c|c|c|c|c|}
\hline \multirow[t]{2}{*}{ Mandi di sungai } & \multicolumn{2}{|c|}{$\begin{array}{l}\text { Leukosituria } \\
\text { Negatif }\end{array}$} & \multicolumn{2}{|c|}{ Leukosituria Positif } & \multicolumn{2}{|c|}{ Total } \\
\hline & $\mathrm{N}$ & $\%$ & $\mathrm{n}$ & $\%$ & $\mathrm{n}$ & $\%$ \\
\hline Ya & 28 & 93,3 & 2 & 6,7 & 30 & 100 \\
\hline Tidak & 28 & 93,3 & 2 & 6,7 & 30 & 100 \\
\hline Total & 56 & 93,3 & 4 & 6,7 & 60 & 100 \\
\hline
\end{tabular}


Pai, Umboh, Wilar: Hubungan kebiasaan mandi...

Tabel 4. Distribusi kejadian leukosituria berdasarkan durasi mandi di sungai

\begin{tabular}{ccccccc}
\hline Durasi (jam) & \multicolumn{2}{c}{ Leukosituria Negatif } & \multicolumn{2}{c}{ Leukosituria Positif } & \multicolumn{2}{c}{ Total } \\
& $\mathrm{n}$ & $\%$ & $\mathrm{n}$ & $\%$ & $\mathrm{n}$ & $\%$ \\
\hline Tidak mandi & 28 & 93,3 & 2 & 6,7 & 30 & 100 \\
$<1$ & 3 & 100 & 0 & 0 & 3 & 100 \\
$>1$ & 25 & 92,6 & 2 & 7,4 & 27 & 100 \\
Total & 56 & 93,3 & 4 & 6,7 & 60 & 100 \\
& & & & & & \\
\hline
\end{tabular}

\section{BAHASAN}

Hasil penelitian yang dilakukan pada 60 orang anak yang berumur 5-12 tahun di Kelurahan Karame didapatkan 50 anak berjenis kelamin laki-laki dan 10 anak berjenis kelamin perempuan. Dari jumlah tersebut yang positif mengalami leukosituria berdasarkan jenis kelamin, perempuan dengan jumlah 3 orang (30\%) orang, sedangkan laki-laki dengan jumlah 1 orang (2\%). Dari data ini didapatkan bahwa persentasi kejadian leukosituria pada anak perempuan lebih tinggi dibandingkan dengan anak laki-laki. ${ }^{12}$

Prevalensi kejadian ISK pada perempuan 3-5\% sedangkan pada laki-laki $\pm 1 \%$. ${ }^{13}$ Sesuai teori yang mengatakan bahwa setelah usia 3 bulan pertama, angka insidensi pada anak perempuan lebih tinggi dari anak laki-laki. ${ }^{3,5}$ Pertumbuhan bakteri Escherichia coli juga menyebabkan infeksi kandung kemih pada wanita. Beberapa wanita lebih rentan terkena infeksi pada sistem genitourinaria yang disebabkan oleh perilaku kurang menjaga kebersihan. Juga karena salah satu faktor anatomi dimana anak perempuan cenderung memiliki muara uretra lebih pendek dibandingkan laki-laki. Peneliti menduga rendahnya angka kejadian leukosituria pada anak lakilaki karena sebagian besar dari mereka telah disirkumsisi. Tanda paling umum ISK adalah saat buang air kecil sering mendadak dan menyakitkan, dorongan untuk buang air kecil lebih sering dari biasanya dan mengalami rasa sakit dan rasa panas saat berkemih. ${ }^{6}$

Dari 60 sampel anak, yang memiliki kebiasaan mandi di sungai berjumlah 30 anak dan yang tidak memiliki kebiasaan mandi di sungai 30 anak. Berdasarkan hasil pemeriksaaan laboratorium, dari 30 anak yang mandi di sungai, yang positif leukosituria berjumlah 2 anak, sedangkan dari 30 anak yang tidak memiliki kebiasaan mandi di sungai yang positif leukosituria berjumlah 2 anak.

Hasil ini berdasarkan perhitungan jumlah leukosit $>5 \mathrm{sel} / \mathrm{LPB}$ atau $>10 \mathrm{sel} / \mu \mathrm{L}$ urin. ${ }^{1}$ Analisis data yang digunakan untuk mengetahui hubungan kebiasaan mandi di sungai dengan kejadian leukosituria ialah uji Fisher's exact test sebagai alternatif dari uji Chi-Square dengan hasil nilai $\mathrm{p}=0,694$ $>0,05$. Dapat disimpulkan bahwa tidak terdapat hubungan bermakna antara mandi di sungai dengan kejadian leukosituria. Dari hasil observasi peneliti di Kelurahan Karame didapatkan kemungkinan penyebab leukosituria ialah kurangnya kesadaran masyarakat akan sanitasi diri dan kebersihan lingkungan, masyarakat masih memiliki kebiasaan membuang kotoran di sungai, dan sebagian masyarakat tidak memiliki toilet sehingga harus buang air besar dan kecil di sungai.

\section{SIMPULAN}

Tidak terdapat hubungan antara kebiasaan mandi di sungai dengan kejadian leukosituria pada anak-anak di Kelurahan Karame.

\section{SARAN}

Disarankan untuk penelitian lanjut dengan menambah jumlah sampel dan pemeriksaan kultur urin untuk mendapatkan hasil yang lebih akurat. 


\section{DAFTAR PUSTAKA}

1. Pardede SO. Leukosituria. In: Noer MS, Soemyarso NA, Subandyah K, Prasetyo RV, Alatas H, Tambunan T, et al. editors. Kompendium Nefrologi Anak. Jakarta: Ikatan Dokter Anak Indonesia, 2011; p. 25-26.

2. Williams GJ, Hodson EH, Issacs D, Craig JC. Diagnosis and Management of Urinary tract infection in children. Journal of Paediatrics and Child Health. 2010;48:291-301.

3. Mahan DJ. Nefrologi dan Urologi. In: Partini Pudjiastuti, editor. Nelson Ilmu Kesehatan Anak Esensial (6th ed). Indonesia: Saunders Elsevier, 2014; p. 662-4.

4. Grabe M, Bjerklund-Johansen TE, Botto H, Cek M, Naber P, Tenke P, et.al. Urinary Tract Infections in Children. In: Grabe M, Bjerklund-Johansen TE, Botto H, Cek M, Naber P, Tenke P, et al. Guidelines on Urological Infections. Barcelona: European Association of Urology, 2010; p. 3444.

5. Gonzales R. Infeksi Saluran Kemih. In: Nelson WE, Kliegman R, Arvin AM, editors. Wahab AS, penerjemah. Ilmu Kesehatan Anak Nelson Vol 3 (15th ed). Jakarta: EGC, 2000; p. 1863-8.

6. Rusdidjas, Ramayati R. Infeksi Saluran Kemih. In: Alatas H, Tambunan T, Trihono PP, Pardede SO, editors. Buku Ajar Nefrologi Anak (2nd ed). Jakarta: FKUI, 2009; p. 142-63.

7. Wagenlehner FME, Weidner W, Naber KG. Advances in Urological Infections. European Urological Review. 2008: 115-17.
8. Endang P. Leukosituria, Bakteriuria dan Pengecatan Gram Urin Sebagai Criteria Diagnostic Infeksi Saluran Kemih Pada Anak. 2001 [cited 5 Oktober 2015] avalaible from: http://eprints.undip.ac.id/12245/

9. Manampirng AE, Kepel BJ. Studi Populasi Bakteri Resisten Merkuri di Daerah Aliran Sungai Tondano Kelurahan Ketang Baru, Manado. Jurnal Ilmiah Sains. 2011;11:26-30.

10. Badan Lingkungan Hidup Provinsi Sulawesi Utara. Kondisi Lingkungan Hidup dan Kecenderungannya. Dalam: Badan Lingkungan Hidup Provinsi Sulawesi Utara. Laporan Status Lingkungan Hidup Daerah Provinsi Sulawesi Utara.Manado: Pemerintah Provinsi Sulawesi Utara, 2009; p. 30-46.

11. Lasut MT, Jensen KR, Arai T, Miyazaki N. An Assesment of Water Quality Along the Rivers Loading to Manado Bay, North Sulawesi, Indonesia. Coastal Marine Science. 2005;29(2): 124-32.

12. Nasution RS. Simple Urinary Tract Infection: Diagnosis and Treatment. Dalam: Dharmeizer, Nainggolan G, Lydya A, editor. The $11^{\text {th }}$ Jakarta Nephrology \& Hypertension Course and Symposium on Hypertension. Jakarta: PERNEFRI (Perhimpunan Nefrologi), 2011; 37-43.

13. Nayak US, Solanki H, Patva P. Utility of Dipstick Versus Urine Culture in Diagnosis of Urinary Tract Infection in Children. Gujarat Medical Journal. 2010;65:20-22. 